\title{
Localization of neurons containing pro-opiomelanocortin-related peptides in the hypothalamus and midbrain of the lizard, Anolis carolinensis: evidence for region-specific processing of $\beta$-endorphin
}

\author{
ROBERT M. DORES, HENRY KHACHATURIAN, STANLEY J. WATSON and HUDA AKIL. \\ Mental Health Research Institute. University of Michigan. Ann Arbor, MI 48109 (U.S.A.
}

(Accepted August 14th. 1984)

Key words: $\beta$-endorphin - $\alpha$-MSH - reptile brain

\begin{abstract}
Immunohistochemical analyses of the lizard brain, following colchicine pretreatment, revealed two populations of POMC-producing cell bodies located in medial-basal hypothalamus and the mesencephalic tegmentum. Analyses of extracts of lizard brain regions by radioimmunoassay and gel filtration chromatography indicate that $\beta$-endorphin-sized and $\alpha$-MSH-sized peptides are the major POMC-related end products. Evidence is presented for region-specific processing of $\beta$-endorphin in the lizard brain.
\end{abstract}

The post-translational processing of pro-opiomelanocortin (POMC), the common precursor for $\mathrm{ACTH}$-related and $\beta$-LPH-related end products has been extensively studied in the mammalian pituitary and brain (for reviews see refs. 1 and 18). Studies on POMC in the brain have focused primarily on the cell body/terminal field network originating from the arcuate nucleus $2,9,14,21$. However, recent anatomical studies on the rat brain have detected a second group of POMC cell bodies in the nucleus tractus solitarius (NTS) ${ }^{15.17,20}$. The presence of two distinct POMC cell body groups in the rat brain is not unique to this species. In this study we present anatomical evidence demonstrating POMC cell bodies in the hypothalamus and mesencephalic tegmentum of the lizard, Anolis carolinensis. Furthermore, analyses of extracts of lizard hypothalamus, forebrain and midbrain indicate that immunoreactive forms of $\beta$-endorphin undergo differential processing in these brain regions.

Previous studies on the pituitary of $A$. carolinensis have shown that in corticotropic cells of the anterior pituitary, the major POMC-related end products are ACTH and opiate-active $\beta$-endorphin ${ }^{4,8}$, while in the intermediate pituitary the major end products are $\alpha$ MSH-sized peptides, CLIP and two forms of opiate- active $\beta$-endorphin ${ }^{5-7}$. Of the latter products, the major form of $\beta$-endorphin has an apparent molecular weight of $3.2 \mathrm{kdalton}$, and the minor form has an apparent molecular weight of 3.5 kdalton. Biosynthetic experiments indicate that the $3.5 \mathrm{kdalton}$ form gives rise to the $3.2 \mathrm{kdalton}$ form as a result of $\mathrm{COOH}$-terminal proteolytic cleavage. Thus, although the overall processing of lizard POMC is similar to the processing pattern observed in mammals ${ }^{12}$, the lizard pituitary POMC systems do differ from the mammalian model. For example, in the anterior pituitary of mammals, the molar ratio of $\beta$-LPH to $\beta$-endorphin is approximately $2: 1^{11}$. In contrast, in the lizard anterior pituitary, the molar ratio of $\beta$-LPH to $\beta$-endorphin, under steady state conditions, is $1: 40^{4.8}$. Furthermore, in the intermediate pituitary of mammals, the major forms of $\beta$-endorphin are alpha, $\mathrm{N}$-acetylated and hence lack opiate bioactivity ${ }^{24}$. The forms of $\beta$-endorphin in the lizard intermediate pituitary are non-acetylated opiate active peptides. Given the distinct features of the lizard POMC pituitary system, we set out to determine whether the POMC system in the lizard brain also showed characteristics distinct from the mammalian model. In this study we focused on two issues: the localization of POMC cell bodies in the lizard brain, and the steady

Correspondence: R. M. Dores, Mental Health Research Institute, University of Michigan, Ann Arbor, MI 48109. U.S.A. 
state levels of $\beta$-endorphin and $\alpha$-MSH in different regions of the lizard brain.

Immunohistochemical anatomical studies were carried out on adult male Anolis carolinensis (average wet wt.. $4 \mathrm{~g}$ ) purchased from Carolina Biological Supply. Ether-anesthetized animals were injected with $4 \mathrm{mg} / \mathrm{ml}$ colchicine solution (maximum dose: 20 $\mu \mathrm{g}$ ) and allowed to recover for $48 \mathrm{~h}$. After this period, the animals were re-anesthetized and sacrificed. To ensure adequate tissue fixation, the cardiovascular system was first flushed with cold normal saline followed by pre-fixing with $50-100 \mathrm{ml}$ of cold buffered $4 \%$ paraformaldehyde. The brain was removed, post-fixed for $2 \mathrm{~h}$ and then transferred to a $15 \%$ sucrose solution for 24 h at $4{ }^{\circ} \mathrm{C}$. Frozen brain sections, $20 \mu \mathrm{m}$ thick, were mounted onto subbed glass slides and stored at $-70{ }^{\circ} \mathrm{C}$.

Immunocytochemical analyses were done by the peroxidase-antiperoxidase procedure as previously described ${ }^{16}$ utilizing rabbit antisera specific for either the middle region of $\mathrm{ACTH}$, the $\mathrm{COOH}$-terminal of $\beta$-endorphin, the COOH-terminal of $\alpha$-MSH or 16 kdalton fragment (antiserum Georgie; kindly provided by Dr. Elizabeth Eipper, The Johns Hopkins School of Medicine). Previous studies have shown that all of these antisera react positively with POMC perikarya in the rat brain?2

In the brain of Anolis, $\beta$-endorphin, ACTH and $\alpha$ $\mathrm{MSH}$ immunoreactivities were localized to perikarya of two distinct neuron groups in the hypothalamus and midbrain (Figs. 1 and 2). In the hypothalamus (Fig. 2A), ACTH immunoreactive parvocellular perikarya $(5-10 \mu \mathrm{m})$ were situated in the medial-basal region which would correspond to the POMC-immunoreactive perikarya in the arcuate nucleus of the rat hypothalamus $2,14.21$. This same group of perikarya was also immunoreactive for $\beta$-endorphin and $\alpha$-MSH and all 3 immunoreactivities could be blocked by preincubation with the appropriate peptide (data not shown, but see Fig. 2D). A second group of neurons in the mesencephalic tegmental area were immunoreactive to ACTH antisera (Fig. 2B) and $\beta$-endorphin antisera (Fig. $2 C$ ). This group of neurons also reacted positively with antisera directed against $\alpha$ MSH (data not shown). All immunoreactivity could be blocked by preincubation of the primary antiserum with $1 \mu \mathrm{M}$ concentration of the appropriate peptide (Fig. 2D). This latter group consisted of large bi- polar neurons $(15-20 \mu \mathrm{m})$, which are apparently without any equivalent representation in mammals. Neither POMC cell body group reacted positively with the 16 kdalton fragment antiserum.

The fiber projections from the hypothalamic perikarya were extensive, innervating several diencephalic and telencephalic limbic structures. These included the medially situated hypothalamic nuclei, preoptic area, midline thalamus, nucleus accumbens, septum, bed nucleus of stria terminalis. olfactory tubercle, amygdala area and medial cortex. In contrast, immunoreactive fibers from the midbrain tegmentum neurons appeared to project to the mesencephalic central gray and other brain stem reticular and raphe nuclei (Khachaturian et al., submitted).

Although the anatomical studies clearly demonstrate that $\beta$-endorphin-related and ACTH-related immunoreactivity are present in discrete neuronal pathways in the lizard brain, this level of analysis cannot unequivocally establish which forms of those peptides are predominant in lizard brain. For example, several studies on the distribution of $\beta$-endorphin in the rat brain indicate that the proteolytic processing of POMC in the mammalian brain resembles the proteolytic processing events observed in the mammalian intermediate pituitary 13.19 .23 . In the hypothalamus of the rat, the major form of $\beta$-endorphin is $\beta$-endorphin $_{1-31^{24}}$, while in the terminal field regions the major forms are $\beta$-endorphin ${ }_{1-27}$ and $\beta$-endorphin $_{1-26^{13}}$ (Akil et al., in preparation). In general, these studies indicate that the levels of acetylated forms of $\beta$-endorphin in the brain are much lower than in the intermediate pituitary. Thus, the major post-translational modification of $\beta$-endorphin in the

Anolis Carolinensis

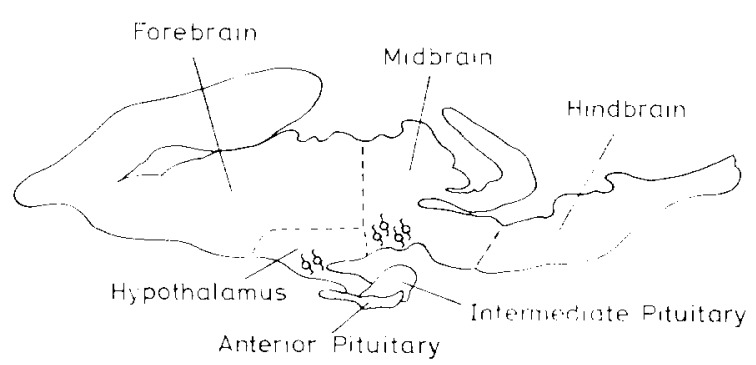

Fig. 1. Schematic diagram of lizard brain in parasagittal section. 

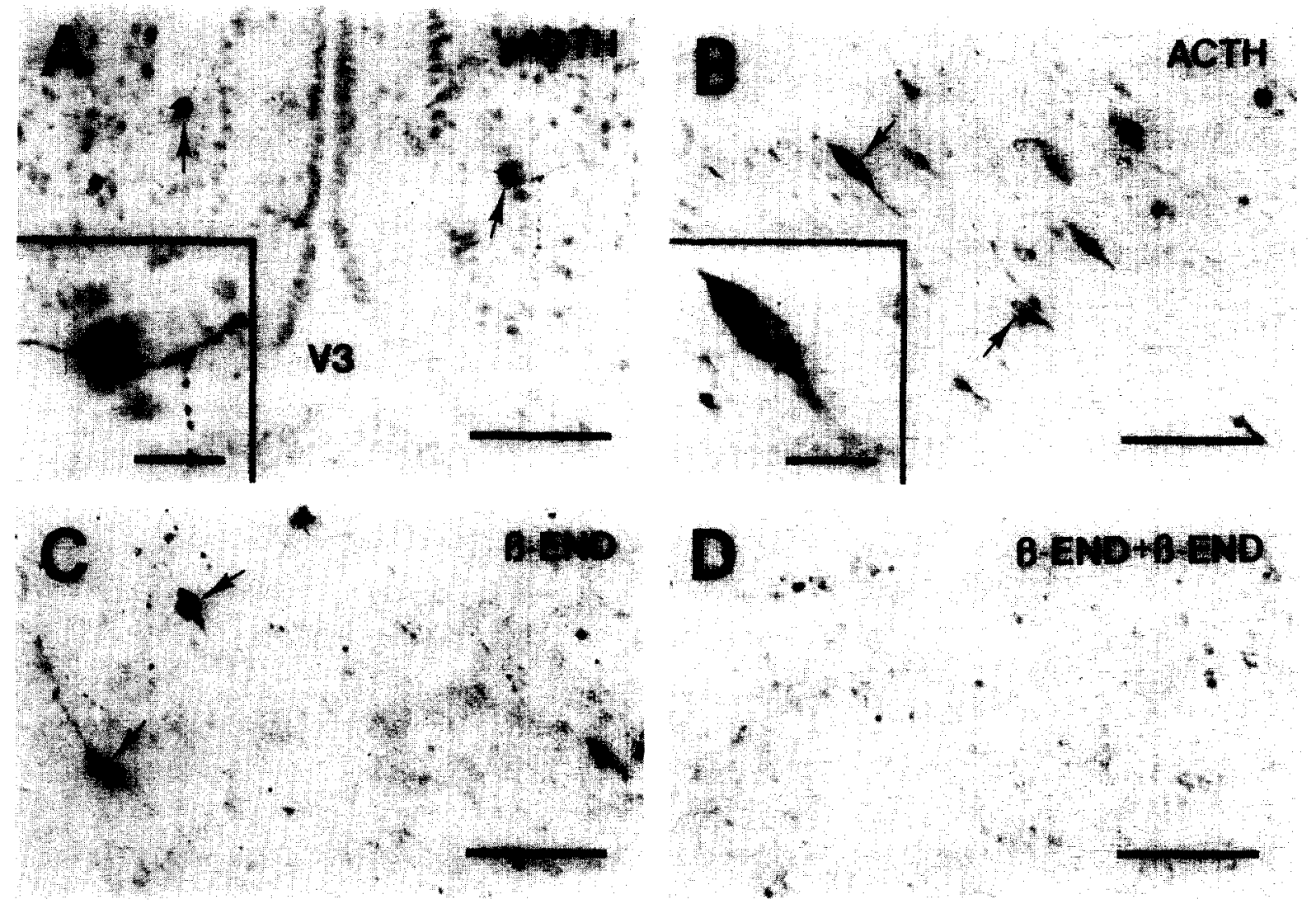

Fig. 2. Immunohistochemical staining of lizard brain. Panels A and B show ACTH-immunoreactive perikarya (arrows) in sections of lizard brain in (A) the region of the arcuate nucleus and $(B)$ the mesencephalic tegmental area. The inserts in $A$ and $B$ are higher magnifications of two specified neurons to demonstrate perikaryal morphology and size. Note that the arcuate perikarya are parvocellular, while the mesencephalic neurons can be classified as magnocellular. Panel $\mathrm{C}$ depicts $\beta$-endorphin $(\beta$-END) immunoreactive neurons in the mesencephalon while in an adjacent section (D) this immunoreactivity was blocked by preadsorption of the primary antibody by $1 \mu \mathrm{M}$ synthetic camel $\beta$-endorphin s-31. $_{1 .}$ V3, third ventricle; bars, $50 \mu \mathrm{m}$; inset bars, $12.5 \mu \mathrm{m}$.

rat brain is $\mathrm{COOH}$-terminal proteolytic cleavage.

In order to further characterize the immunoreactivity forms of $\beta$-endorphin-related and ACTH-related material in the lizard brain, extracts of hypothalamus, forebrain, midbrain, and intermediate pituitary (Fig. 1) were separately fractionated on a Sephadex G-50 column equilibrated in $10 \%$ formic acid. Aliquots of column fractions were analyzed by radioimmunoassay with heterologous antisera specific for either the $\mathrm{COOH}$-terminal of mammalian $\beta$-endorphin (antiserum Brenda; final dilution 1:30,000) or the COOH-terminal of mammalian $\alpha$-MSH (provided by Dr. R. Martin, University of Ulm West Germany; final dilution 1:30,000). The column was calibrated with the following radiolabeled lizard standards: $\left[{ }^{3} \mathrm{H}\right]$ arginine-labeled POMC, $\left[{ }^{3} \mathrm{H}\right]$ arginine-labeled $\beta$ - LPH, $\left[{ }^{3} \mathrm{H}\right]$ tyrosine-labeled 3.5 kdalton $\beta$-en- dorphin, $\left[{ }^{3} \mathrm{H}\right]$ tyrosine-labeled 3.2 kdalton $\beta$-endorphin, and [ $\left.{ }^{3} \mathrm{H}\right]$ typtophan-labeled $\alpha$-MSH. These peptides were prepared by biosynthetically labeling lizard intermediate pituitaries in primary cultures as previously described ${ }^{5-7}$. The Sephadex G-50 chromatography system was selected because under denaturing conditions the $3.5 \mathrm{kdalton}$ and the $3.2 \mathrm{kdal}$ ton forms of lizard $\beta$-endorphin can be resolved as two distinct overlapping peaks ${ }^{7}$. Fig. 3, panel D, depicts the elution of immunoreactive $\beta$-endorphin-related and $\alpha$-MSH-related substances, isolated from an extract of lizard intermediate pituitary as compared to the elution of the radiolabeled lizard standards. As expected from previous studies', the major peak of $\beta$-endorphin-sized material eluted with the same mobility as the 3.2 kdalton $\beta$-endorphin standard. Minor peaks of immunoreactivity which corre- 

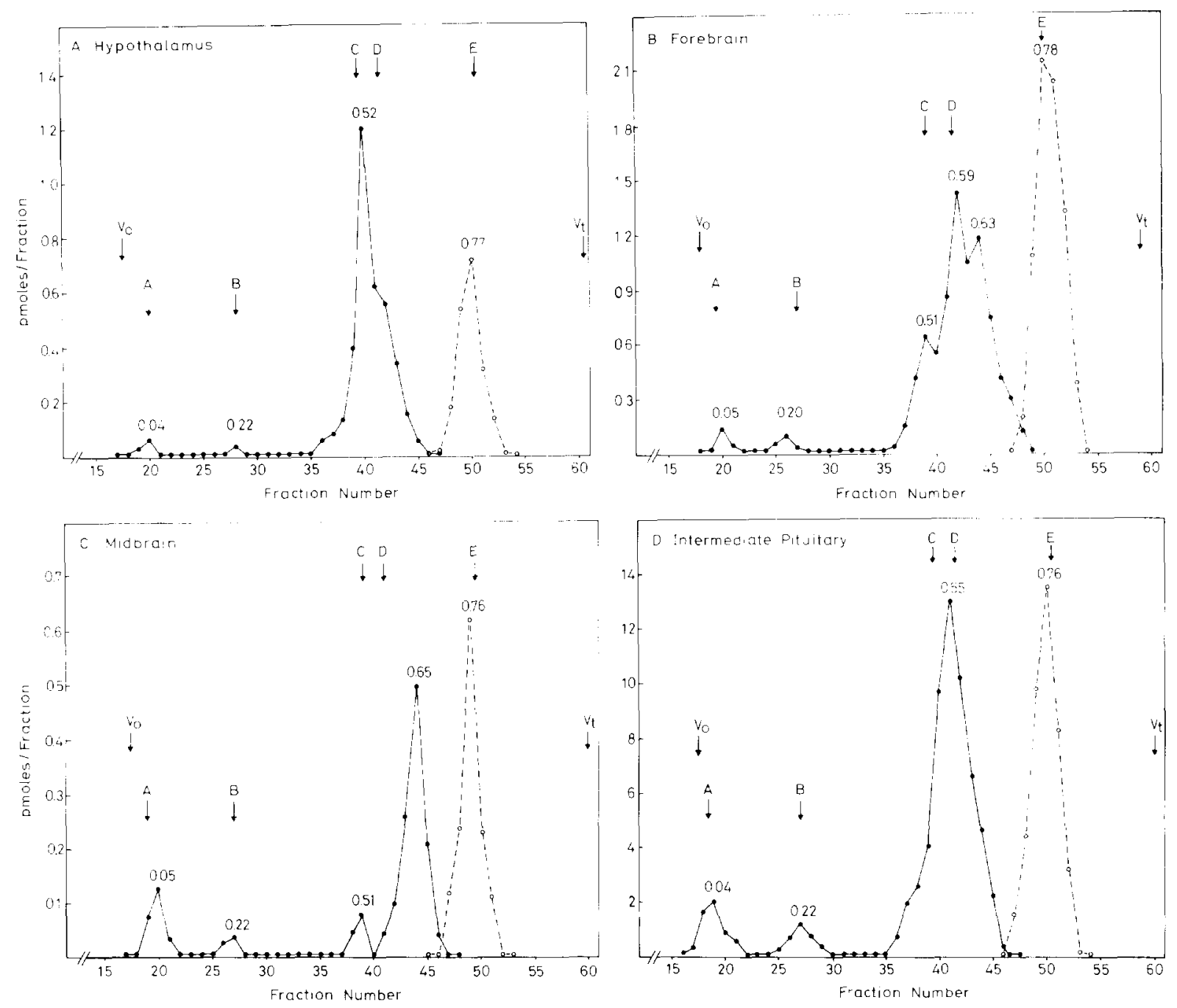

Fig. 3. Gel filtration chromatography of lizard intermediate pituitary and brain. 'Ihe intermediate pituitary, hypothalamus, forebrain and midbrain were obtained from 10 male lizards and separately acid-extracted. Brain dissections were done as outlined in Fig. 1. Each acid extract was concentrated, dissolved in $400 \mu \mathrm{l}$ of $10 \%$ formic acid, $0.1 \%$ bovine serum albumin buffer and separately chromatographed on a Sephadex G-50 (fine) column equilibrated with the same buffer. The fraction size was $600 \mu l$ and the flow rate was 1 $\mathrm{ml} / \mathrm{h}$. Aliquots of column fractions were concentrated and redissolved in $150 \mu \mathrm{l}$ of $50 \mathrm{mM}$ sodium phosphate buffer. $\mathrm{pH} 8.2,0.1 \%$ bovine serum albumin buffer for analysis by radioimmunoassay. The $V_{0}$ was marked by bovine serum albumin and $V_{t}$ was marked by $2, \beta$ mercaptoethanol, both detected at $\mathrm{A}_{280}$. The following biosynthetically labeled lizard standards were run separately: (A) POMC, (B) $\beta$-LPH, (C) 3.5 kdalton $\beta$-endorphin. (D) 3.2 kdalton $\beta$-endorphin and (E) $\alpha$-MSH. The recovery of immunoreactivity following gel filtration averaged $90 \%$.

sponded to lizard POMC and $\beta$-LPH were also detected. The $\alpha$-MSH antiserum (Martin) detected a single peak of $\alpha$-MSH immunoreactivity which was approximately equimolar to the peak of $\beta$-endorphin-sized material.

Analysis of the lizard brain suggests a similar processing pattern. Fractionation of an extract of the hypothalamus (Fig. 3, panel A) revealed one major and two minor peaks of $\beta$-endorphin-related material. The minor peaks correspond to lizard POMC and
$\beta$-LPH and represent, respectively $3 \%$ and $1 \%$ of the total immunoreactivity. The remaining $96 \%$ of the immunoreactivity eluted as a major peak corresponding to $3.5 \mathrm{kdalton} \beta$-endorphin. A shoulder on the trailing edge of this peak was also detected which would correspond to $3.2 \mathrm{kdalton} \beta$-endorphin. A peak of $\alpha$-MSH-sized material roughly equimolar to the $\beta$-endorphin-sized material was also detected. This profile is analogous to the profile for $\beta$-endorphin in the rat hypothalamus ${ }^{24}$. 
In the lizard forebrain, an area rich in $\beta$-endorphin fibers (Khachaturian et al., submitted), a shift in the $\beta$-endorphin immunoreactivity profile was observed relative to the profile for the hypothalamus. This shift was in favor of lower molecular weight forms of immunoreactive $\beta$-endorphin (Fig. 3, panel B). In the forebrain extract, $\beta$-endorphin-sized material can be resolved into 3 overlapping peaks. The major peak $\left(K_{d}=0.59\right)$ co-eluted with 3.2 kdalton $\beta$-endorphin. A shoulder of immunoreactivity on the leading edge of this peak $\left(K_{d}=0.51\right)$ corresponded to 3.5 kdalton $\beta$-endorphin. A second shoulder on the trailing edge of this peak $\left(K_{d d}=0.63\right)$ corresponds to material with an apparent molecular weight between 2.5 kdalton and 3.0 kdalton. The peaks of $\beta$-endorphinsized material were roughly equimolar to a peak of immunoreactive $\alpha$-MSH-sized material $\left(K_{d}=0.78\right)$. This profile is clearly distinct from the profiles of immunoreactivity observed for either the lizard intermediate pituitary or hypothalamus. These data would suggest that as $\beta$-endorphin is transported from the cell bodies in the hypothalamus to terminals in the forebrain, the material is proteolytically cleaved to lower molecular weight forms.

Analysis of an extract of lizard midbrain yielded a third distinct $\beta$-endorphin profile for the lizard brain (Fig. 3, panel C). In this region 3 minor peaks and one major peak of immunoreactive $\beta$-endorphin were detected. The minor peaks corresponded to lizard POMC, $\beta$-LPH and 3.5 kdalton $\beta$-endorphin and represented, respectively, $16 \%, 5 \%$, and $9 \%$ of the total $\beta$-endorphin immunoreactivity. The major peak of immunoreactivity $\left(K_{d}=0.65\right)$ represents $70 \%$ of the total $\beta$-endorphin immunoreactivity and has an apparent molecular weight of $2.6 \mathrm{kdalton}$. The total $\beta$-endorphin related immunoreactivity is roughly equimolar to a peak of $\alpha$-MSH-sized material $\left(K_{d}=\right.$ 0.76 ). At present, it is not possible to determine how much of the immunoreactivity in the midbrain originates from the hypothalamic POMC cell bodies as compared to the mesencephalic POMC cell bodies. However, it is tempting to propose that the hypothalamus/forebrain represents one processing pattern and the midbrain another processing pattern. In terms of the overall content of $\beta$-endorphin in the lizard brain relative to the intermediate pituitary, after correcting for the milligram wet wt. of tissue, there is 100 -fold less $\beta$-endorphin-related immunoreactivity in the hypothalamus, 260-fold less in the forebrain. 1320 -fold less in the midbrain and 1650-fold less in the hindbrain.

In summary, the POMC system in the lizard brain exhibits some features in common with the mammalian brain, as well as several unique characteristics. Anatomically, two POMC cell body groups are present in the lizard brain. As in mammals and other nonmammalian vertebrates that have been studied $3 . .1$. a major cell body group is present in the arcuate region of the hypothalamus. In the rat brain, a second POMC cell body group has been detected in the dorsal medial medulla ${ }^{15,17,20}$. In contrast, in the lizard. we have noted a previously undetected POMC cell group in the ventral mesencephaton. These midbrain POMC cell bodies have not been observed in the brain of other vertebrates. In terms of post-translational processing, the lizard brain is similar to the mammalian brain in that $\beta$-endorphin-sized and $\alpha$ MSH-sized peptides represent the major forms of POMC end products. In this respect, post-translational processing of POMC in the brain of vertebrates is more similar to the proteolytic processing events observed in the vertebrate intermediate pituitary rather than the anterior pituitary. Although the immunohistochemical studies indicated that antisera directed against the middle region of $\mathrm{ACTH}$ reacted positively with POMC-related cell bodies in the lizard brain. analysis of brain region extracts by radioimmunoassay detected only trace levels of ACTH-sized material (data not shown). Further studies are needed to clarify the nature of the ACTH-related immunoreactivity in the lizard brain.

Based on these gel filtration studies it appears that in the lizard brain the trend is to proteolytically cleave $\beta$-endorphin to lower molecular weight forms in the terminal field regions. Further characterization of the forms of lizard $\beta$-endorphin in the brain by ion exchange chromatography and the determination of the opiate bioactivity of these forms awaits future analysis.

We wish to thank Dr. R. Martin for providing $\alpha$ MSH antiserum and we are grateful to G. Baldrighi for preparation of the figures and A. Henry for manuscript preparation. This work was supported by NIDA Grant DA 02265 to S.J.W. and H.A. and the Raphael Foundation. 
1 Akil, H. and Watson, S. J.. $\beta$-Endorphin and biosynthetically related peptides in the CNS. In L. Iversen, S. D. Iversen and S. H. Snyder (Eds.), Handbook of Psychopharmacology, Vol. 16, Plenum, 1983, pp. 209-253.

2 Bloom, F. E., Rossier, J., Battenberg, E. L. F., Bayon, A., French. E., Henricksen, S. J., Siggins, G. R., Segal, D. Browne, R., Long. N. and Guillemin, R., $\beta$-Endorphin: cellular localization, electrophysiological and behavioral effects. In E. Costa and M. Trabucchi (Eds.). The Endorphins: Advances in Biochemical Psychopharmacology, Vol. 18. Raven Press, New York, 1978, pp. 89-109.

3 Doerr-Schott. J., Dubois, M. P. and Licht, C. Immunohistochemical localization of substances reactive to antisera against $\ell$-and $\beta$-endorphin and met-enkephalin in the brain of the frog. Rana temporaria L. Cell. Tiss. Res., 217 (1981) $79-92$.

4 Dores, R. M., Localization of multiple forms of ACTH-and $\beta$-endorphin-related substances in the pituitary of the reptile, Anolis carolinensis, Peptides, 3 (1982) 913-924.

5 Dores, R. M. Evidence for a common precursor for $\alpha$ MSH and $\beta$-endorphin in the intermediate lobe of the pituitary of the reptile Anolis carolinensis, Peptides, 3 (1982) 925-935.

6 Dores, R. M. . Further characterization of the major forms of reptile $\beta$-endorphin, Peptides, 4 (1983) 897-905.

7 Dores. R. M. and Surprenant, A., Biosynthesis of multiple forms of $\beta$-endorphin in the reptile intermediate pituitary. Peptides, 4 (1983) 889-896.

8 Dores, R. M. and Surprenant, A., In vitro synthesis of ACTH- and $\beta$-endorphin-related substances in the pars distalis of Anolis carolinensis, Gen. comp. Endocr., in press

9 Dube, D., Lissitzky, J. C.. Leclerc. R. and Pelletier. G.. Localization of $\alpha$-melanocyte-stimulating hormone in rat brain and pituitary, Endocrinology, 102 (1978) 1283-1291.

10 Dubois, M. P.. Billard, R., Breton, B. and Petor, R., Comparative distribution of somatostatin, LHRH, neurophysin and $\alpha$-endorphin in the rainbow trout: an immunocytochemical study, Gen. comp. Endocr., 37 (1979) 220-232.

11 Eipper, B. A. and Mains. R. E., Existence of a common precursor to ACTH and endorphin in the anterior and intermediate lobes of the rat pituitary, J. Supramol. Struct., 8 (1978) 247-262.

12 Eipper, B. A. and Mains, R. E., Structure and function of pro-adrenocorticotropin/endorphin and related peptides,
Endocr. Rev., 1 (1980) 247-262

13 Evans, C. J., Lorenz, R., Weber, E. and Barchas, J. D. Isolation and characterization of $\alpha-\mathrm{N}$-acetyl- $\beta$-endorphin(1-26) from the rat posterior/intermediate pituitary lobe, Biochem. Biophys. Res. Commun., 15 (1981) $897-904$.

14 Jacobowitz. D. M. and O'Donohue, T. L. $\alpha$-Melanocytestimulating hormone: immunohistochemical identification and mapping in the neurons of the rat brain. Proc. nat. Acad. Sci. U.S.A., $75(1978) 6300-63(4)$.

15 Joseph, S. A., Pilcher, W. H. and Bennett-Clarke, C., Immunocytochemical localization of ACTH perikarya in nucleus tractus solitarius: evidence for a second opiocortin neuronal system, Neurosci. Lett. . 38 (1983) 221-225.

16 Khachaturian, H. Watson, S. J., Lewis, M. E.. Coy, D. Goldstein, A. and Akil. H., Dynorphin immunocytochemistry in the rat central nervous system. Peptides, 3 (1982) 941-954.

17 Khachaturian. H.. Alessi. N. E., Munfakh. N. and Watson, S. J., Ontogeny of opioid and related peptides in the rat CNS and pituitary: an immunocytochemical study, Life Sci., 33 (1983) 61-64

18 O'Donohue, T. L., The opiomelanotropinergic neuronal and endocrine systems, Peptides, 3 (1981) 333-344

19 O'Donohue, T. L., Miller. R. L. and Jacobowitz, D. M. Identification: characterization and stereo-taxic mapping of intraneuronal $\alpha$-melanocyte stimulating hormone-like immunoreactive peptides in discrete regions of the rat brain, Brain Research, 176 (1979) 101-123.

20 Schwartzberg. D. G and Nakane, P. K.. ACTH-related peptide neurons within the medulla oblongata of the rat. Brain Research, 276 (1983) 351-356.

21 Watson, S. J., Akil, H., Richard. C. W. and Barchas, J. D., Evidence for two separate opiate peptide neuronal systems, Nature (Lond.), 275 (1978) 226-228.

22 Watson, S. J.. Akil. H. and Walker, J. M. Anatomical and biochemical studies of the opioid peptides and related substances in the brain, Peptides, 1 (Suppl. 1) (1980) 11-20.

23 Zakarian. S. and Smyth, D., Distribution of active and in active forms of $\beta$-endorphin in rat pituitary and brain. Proc nat. Acad. Sci. U.S.A., 76 (1979) 5972-5976.

24 Zakarian. S. and Smyth, D. G.. Review article: distribution of $\beta$-endorphin related peptides in rat pituitary and brain. Biochem. J., 202 (1982) 561-571. 